Boston University School of Law Scholarly Commons at Boston University School of Law

Faculty Scholarship

$6-2018$

\title{
Martin Luther King Jr. And Pretext Stops (and Arrests): Reflections on How Far We Have Not Come Fifty Years Later
}

Tracey Maclin

Boston Univeristy School of Law

Maria Savarese

Boston University School of Law

Follow this and additional works at: https://scholarship.law.bu.edu/faculty_scholarship

Part of the Law and Race Commons

\section{Recommended Citation}

Tracey Maclin \& Maria Savarese, Martin Luther King Jr. And Pretext Stops (and Arrests): Reflections on How Far We Have Not Come Fifty Years Later, 49 University of Memphis Law Review (2018).

Available at: https://scholarship.law.bu.edu/faculty_scholarship/287 


\section{BU School of Law}

\section{MARTIN LUTHER KING JR. AND PRETEXT STOPS (AND ARRESTS): REFLECTIONS ON HOW FAR WE HAVE NOT COME FIFTY YEARS LATER}

Boston University School of Law Public Law \& Legal Theory Paper No.

18-12

University of Memphis Law Review, Vol. 49 June 2018

Tracey Maclin and Maria Savarese Boston University School of Law 


\title{
Martin Luther King Jr. and Pretext Stops (and Arrests): Reflections on How Far We Have Not Come Fifty Years Later
}

\author{
By: TRACEY MACLIN* \& MARIA SAVARESE**
}

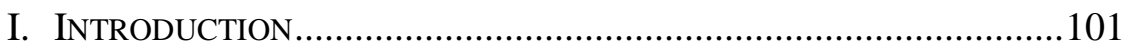

A. Pretext Stops in America .................................................103

B. Pretext Stops and the Fourth Amendment .......................108

II. THE IMPACT OF WHREN V. UNITED STATES ..................................111

III. The NumBers TODAY— “DRIVING WhILE BLACK” REMAINS A

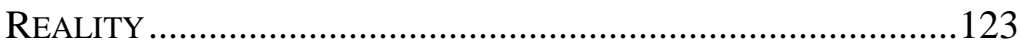

A. Stanford Open Policing Project .....................................123

B. Department of Justice Special Reports ...........................125

C. Department of Justice Investigation of the Ferguson, Missouri Police Department ..........................................126

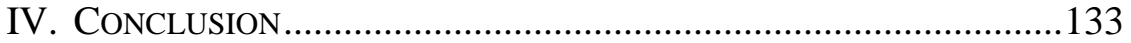

\section{INTRODUCTION}

By January 1956 the Montgomery Bus boycott was in fullswing. Black citizens in Montgomery, Alabama, were refusing to ride the city's private buses to protest racially segregated seating. At the midpoint of the twentieth century, protests against racial segregation in the South generally, and Montgomery specifically, raised serious and dangerous problems for Montgomery's black community. ${ }^{1}$ The

* Professor of Law, Boston University School of Law.

** Class of 2018, Boston University School of Law.

1. See Randall Kennedy, Martin Luther King's Constitution: A Legal History of the Montgomery Bus Boycott, 98 YALE L.J. 999, 1005-10 (1989). White officials and business leaders in Montgomery were not happy about the bus boycott. Predictably, black leaders of the boycott "were threatened, and verbal intimidation was 
bus boycott also presented practical concerns for African Americans living and working in Montgomery. "To a largely uneducated people among whom the most common occupations were maid and day laborer, the loss of what was for many their most important modern convenience-cheap bus transportation-left them with staggering problems of logistics and morale." 2 The problems for the black community worsened when the Montgomery police commissioner threatened to arrest taxi drivers who charged black boycotters less than the minimum forty-five-cent fare. ${ }^{3}$ In response to this threat, the black community organized a car-pool system that would transport bus boycotters throughout the city. ${ }^{4}$

On the afternoon of January 26, 1956, twenty-seven-year-old Martin Luther King Jr. had finished his day of work at the Dexter Avenue Baptist Church in Montgomery. ${ }^{5}$ On his drive home, King stopped his vehicle to offer a ride to a group of bus boycotters standing at a downtown car-pool location. ${ }^{6}$ After the boycotters entered King's car, two motorcycle policemen pulled-in behind King's vehicle. ${ }^{7}$ While everyone in King's car tried to remain calm, the police continued to follow King's car. ${ }^{8}$ At the next car-pool location, when some of King's passengers began to exit, one of the policemen pulled next to King's window, stating: “Get out, King. You're under arrest for speeding thirty miles an hour in a twenty-five-mile zone." 9 While stunned by the police action, King did not protest. He was arrested and

quickly superseded by potentially lethal force as bombs were detonated at the homes of [Martin Luther King Jr.] and [E.D.] Nixon,” an elder statesman of black civil rights activists in Montgomery. Id. at 1027-28 (citations omitted).

2. TAYlor Branch, Parting the WATERS: AMERICA IN THE King YeARS 1954-63, at 145 (1988).

3. Id.

4. Id.

5. Id. at 160 .

6. Id.

7. Id.

8. Id.

9. Id. 
taken to the Montgomery City Jail where he was processed, fingerprinted, and jailed with other black prisoners, including a schoolteacher who was also arrested during the bus boycott. ${ }^{10}$

Even in 1956, stopping (and arresting) blacks for petty or nonexistent offenses had a long-standing pedigree. In America, police targeting blacks for arbitrary and disproportionate searches and seizures is a tradition as old as the nation itself. ${ }^{11}$ What happened to King is known as an investigatory or "pretext" stop. The pretext for the stop was the commission of a traffic offense-allegedly driving thirty miles per hour in a twenty-five mile-per-hour zone-but the real reason to stop and arrest King had nothing to do with the alleged speeding violation. On the contrary, the Montgomery police wanted to intimidate King and send a message to Montgomery's black community.

It has been over sixty years since Martin Luther King Jr. was subjected to this arbitrary and discriminatory police practice.[JH: it has been more than sixty years since 1956] Surely, things have changed in America. After the demise of the Jim Crow system, the enactment of federal civil rights legislation protecting blacks from discriminatory application of state and local laws, ${ }^{12}$ as well as several decades of Supreme Court rulings enforcing the rights of black citizens, ${ }^{13}$ it would seem that law enforcement officials can no longer perform this type of arbitrary and bigoted policing.

\section{A. Pretext Stops in America}

Although much has changed in America, investigatory or pretext stops unfortunately remain ubiquitous. As in King's case, these

10. Id.

11. SAlly E. Hadden, Slave Patrols: LaW AND Violence in Virginia AND THE CAROLINAS 110 (2001) (citation omitted) (describing the laws that required black slaves who traveled beyond their homes to possess slave passes: "Slave patrols frequently looked at slave passes while making their rounds. Laws required the slave to carry a pass, or ticket, from her master, which permitted the slave to leave the plantation. A specific pass stated the slave's name, where she had permission to go, on what date, how long the pass was good for ... and bore the owner's signature.”).

12. See, e.g., Civil Rights Act of 1964, 42 U.S.C. § 2000e-2 (1991).

13. See, e.g., Batson v. Kentucky, 476 U.S. 79 (1986); Loving v. Virginia, 388 U.S. 1 (1967); Browder v. Gayle, 352 U.S. 903 (1956); Brown v. Bd. of Educ., 347 U.S. 483 (1954). 
stops are not aimed at enforcing the traffic code. Rather, police "making investigatory stops commonly have decided to carry out a criminal investigation before they make the stop; they then identify, or create, a pretext to justify the stop.” ${ }^{14}$ Put differently, a pretext stop is a police practice "where the intent is not to sanction a driving violation but to look for evidence of more serious criminal wrongdoing." ${ }^{15}$ Various types of law enforcement agencies utilize pretext stops, and high-ranking police officials endorse pretext stops as a crime control measure. ${ }^{16}$ Indeed, over two decades ago investigatory stops were given a major boost when the federal government actively encouraged state and local police departments to use traffic laws as a basis for stopping cars suspected of drug smuggling. ${ }^{17}$

14. Charles R. Epp et Al., Pulled Over: How Police Stops Define Race AND CITIZENSHIP 59 (2014); id. at 8 ("The investigatory stop is made not to enforce traffic laws or vehicle codes but to investigate the driver. Is this driver carrying a gun or illegal drugs? What is he up to? Why is he in this neighborhood? Is there a warrant for his arrest?”). Because police cannot conduct a stop without probable cause or reasonable suspicion of a crime or traffic violation, "most investigatory stops are nominally justified by minor violations." $I d$.

15. Id. at 30. A traffic code is well suited for pretext stops because police "may manipulate [the traffic laws] 'to justify detention and interrogation of persons suspected of more serious crimes." ' Josh Bowers, Annoy No Cop, 166 U. PA. L. REV. 129, 157 n.126 (2017) (quoting WAYNE R. LAFAVE, ARREST: THE DECISION TO TAKE A Suspect INTO CuSTODY 87-88 (Frank J. Remington ed., 1965)). When used in this manner, the traffic code is the equivalent of a vague statute. Id.; see also LAFAVE, supra, at 87-89 (noting that police use vague laws as pretext to investigate suspicious persons).

16. EPP ET AL., supra note 14, at 10 (“Although police departments differ in many ways - big cities versus small towns, urban departments versus state highway patrol agencies, traditional versus progressive agencies - the investigatory stop has spread widely among these agencies.”); id. at 12 (citation omitted) ("Police officers particularly believe that investigatory stops are among their most effective tools for finding and arresting criminals and preventing crimes. In many departments, very large proportions of all arrests are made in 'routine' investigatory traffic stops.”). Even after racial profiling became politically unacceptable in the 1990s, "every official condemnation of racial profiling by the leaders of professional policing was accompanied in its official text by a full-throated defense of investigatory stops." Id. at 49 (citation omitted).

17. See EPP ET AL., supra note 14, at 27 (noting that pretext stops were revived and encouraged, in part, through "research by policing scholars claiming that investigatory stops were among professional policing's most effective crime-fighting tools," 
When discussing police stops it is important to distinguish between pretext stops, which are fishing expeditions for criminality, and ordinary traffic stops, which are performed to genuinely enforce the traffic code or to promote traffic safety. During ordinary traffic stops, "officers' discretionary choices are focused on traffic-law violations."18 A pretext stop is a very different police tactic: "The distinction between traffic-safety and investigatory stops is the key to sorting out how and when race matters in police stops.”19

and the "development of remarkably detailed knowledge about how, tactically, to effectively carry out these stops; Gary Webb, DWB [Driving While Black], EsQUIRE, Apr. 1999, at 118,C reprinted in EsQuiRE, Jan. 29, 2007, https://www.esquire.com/news-politics/a1223/driving-while-black-0499/ (describing Operation Pipeline, which was the federal program designed to identify drug couriers on the nation's highways).[JH: per BB 1.4 books should come first] This body of knowledge grew out of the federal government's war on drugs and the police training provided as part of that initiative, which spread ideas about how to carry out investigatory stops so as to discover contraband in vehicles. This research and the accompanying improvements in stop tactics and training convinced police leaders that investigatory stops were an effective strategy.”).

Although he did not invent the pretext traffic stop, Bob Vogel, a former Florida State Trooper and later the sheriff of Volusia County, Florida, helped perfect the practice as we know it today. As Professor David Harris details in his book PROFILES IN InJUSTICE: Why RACIAL PROFILING CANNOT WORK (2002), Vogel began making a name for himself and pretext stops by conducting several successful drug busts by stopping drivers on Interstate 95 in Florida between February 1984 and March 1985. Id. at 22. According to Vogel, he amassed “a list of . . 'cumulative similarities' Vogel prefers not to use the word profile"-in drivers who possessed drugs. Id. Vogel then used these characteristics when deciding which drivers to stop. Id. Initially, courts were skeptical of Vogel's technique and found some of his stops violated the Fourth Amendment. Id. at 22-23 (citing United States v. Smith, 799 F.2d 704 (11th Cir. 1986)). "But Vogel soon discovered a way around these problems. Instead of using the similarities themselves as the legal justification for the stop, Vogel began stating that the traffic offense was the reason he stopped the car." Id. at 23. Vogel went on to "conduct[] training classes for the DEA's Operation Pipeline.” Id. at 22; see also 4 WAyne R. LAFAVE, SEARCh AND SEIZURE: A TREATISE ON THE Fourth AMENDMENT § 9.3, at 470 n.2 (5th ed. 2012); Albert W. Alschuler, Racial Profiling and the Constitution, 2002 U. CHI. LEGAL F. 163, 170 n.25 (describing how "[t]he federal government has strongly encouraged state and local law enforcement officers to view the highway as a battleground in the war on drugs," referencing Operation Pipeline).

18. EPP ET AL., supra note 14, at 53.

19. Id. at 59. 
From one perspective, the use of pretext stops in the War on Drugs specifically, and to fight crime generally, raises no legal alarm. For most white Americans, modern application of this practice may seem annoying but it is worth the cost in the fight against crime: A motorist is stopped by the police. The officer then questions the motorist about his or her travel plans (and if there are passengers, they are also questioned). Finally, a traffic summons or ticket may be issued. While bothersome, this practice, viewed in the aggregate, does not amount to a constitutional crisis. Moreover, on rare occasion, criminality is exposed as a result of the stop. ${ }^{20}$

Black Americans, however, have a distinctly different perception of the situation. For King, the pretext stop was much more than a "stop." ${ }^{21}$ The upshot was a frightening ride to jail: At one point during the ride, "[p]anic seized" King because he believed the police were going to lynch him. ${ }^{22}$ Today, the modern pretext stop is on display when a black motorist is seen standing on the side of a highway or city street while police-typically white officers-search his vehicle.

20. The public's perception of the consequences of pretext stops is distorted. Local news outlets will occasionally highlight the major drug bust or discovery of weapons during a traffic stop. Rarely, however, does local news media describe the many innocent persons who are stopped and searched but no evidence of criminality is discovered. Likewise:

Judges see only cases in which stops and searches yield illegal drugs or illegal guns. They typically conclude that the harm to a driver who is found with illegal drugs was outweighed by the benefits of reducing crime. Judges do not see the many more stops and searches that yield no drugs or guns, and they rarely ask whether these stops harm the innocent, who are subjected to intrusive questions, searches, handcuffing, and worse. Even the police, those closest to the stop, rarely consider the possibility that investigatory stops may cause deep and lasting harm.

Id. at 134 .

21. Although the arrest of King for a speeding violation was obviously pretextual, under the Supreme Court's modern interpretation of the Fourth Amendment the arrest was constitutional. See Arkansas v. Sullivan, 532 U.S. 769 (2001) (interpreting Whren v. United States, 517 U.S. 806 (1996), which ruled that pretextual traffic stops did not violate the Fourth Amendment, as also controlling the constitutionality of pretextual arrests).

22. BRANCH, supra note 2 , at 160 . 
Study after study has demonstrated that African Americans are targeted for pretext stops at a rate greater than white Americans:

The investigatory stop is why blacks are stopped at much higher rates than whites and why police pursue intrusive lines of questioning and searches more commonly in stops of blacks than of whites. While whites mainly experience conventional traffic-safety stops, racial minorities — blacks especially_commonly experience investigatory stops.... This racial difference in police practices and people's lived experience and shared knowledge of these practices is why black people commonly rate stops that they have experienced as unfair, while whites are generally more sanguine about stops that they have experienced. It is a key reason why, compared to whites, African Americans so distrust the police. $^{23}$

For blacks, particularly black men, a pretext stop is unequivocal notice of their inferior status in America. As Don Jackson, a former police officer, put it not too long ago: "The black American finds that the most prominent reminder of his second-class citizenship are the police." 24

Surely, some must be thinking that Jackson exaggerates. Not so. Jackson's words were prompted, in part, by what happened to him at the hands of police. On January 14, 1989, Jackson, a former police officer from Hawthorne, California, attempted to document that Long Beach, California police were targeting and harassing minority citizens who lived in and visited Long Beach. Jackson and a companion were stopped (ironically) while driving along Martin Luther King Boulevard. When Jackson asked the police why he was stopped, an officer pushed Jackson through a plate-glass store window. Unknown to the police, an NBC camera crew filmed the entire incident. ${ }^{25}$ What happened to Jackson is experienced by thousands of black motorists

23. EPP ET AL., supra note 14, at 8.

24. Don Jackson, Police Embody Racism to My People, N.Y. TimES, Jan. 23, 1989, at A25.

25. Bill Girdner, Charge of Racism by California Police Is Latest in Long Line, Bos. GLOBE, Jan. 19, 1989. 
yearly, with lesser or greater consequences. Further, empirical studies show that other blacks share Don Jackson's view of the police. Even when officers are polite during pretext stops, blacks describe "fear and resentment of the experience." ${ }^{26}$ White drivers, by contrast, are not routinely targeted for this practice. Thus, the ultimate problem is not racist police officers, or even rude behavior by police during investigatory stops: "What makes inquisitive police stops so offensive to so many African Americans and Latinos is not that the officers carrying them out are impolite or even frankly bigoted, but that these stops are common, repeated, routine, and even scripted.”27

\section{B. Pretext Stops and the Fourth Amendment}

No doubt, many readers must be thinking that the Constitution has something to say about pretext stops. ${ }^{28}$ What we have described is arbitrary and discriminatory police behavior. For a nation that is rightly proud of some of its constitutional heritage, pretext stops should be an anathema. The Fourth Amendment to the Constitution, which protects us against unreasonable searches and seizures, should presumably bar pretext stops. Whenever the police stop or "pull over" a motorist for a traffic offense, they have seized that motorist within the meaning of the Fourth Amendment. ${ }^{29}$ Why are pretext stops "reasonable"? Why are police acting reasonably when they stop a vehicle

26. EPP ET AL., supra note 14, at 2.

27. Id. at 6 .

28. Cf. Eric F. Citron, Note, Right and Responsibility in Fourth Amendment Jurisprudence: The Problem with Pretext, 116 YALE L.J. 1072, 1074 (2007) ("There [is] something about this kind of police mindset - this liberated space for bad intentions - that should give the individual citizen both a moment of pause and the hope, perhaps, that the Constitution forbids this form of roving pretextual surveillance.”); id. at 1114 ("We, as a citizenry, should be concerned with pretext on the part of the police because, perhaps more than anything else, pretext indicates that it may not be appropriate to trust them to responsibly discharge the powers we have granted them for the ends that these powers were intended to serve. Indeed, pretext ought to be a core problem for the Fourth Amendment because it represents a breach of trust.”) (emphasis added).

29. Brendlin v. California, 551 U.S. 249, 251 (2007) (finding that in addition to seizing the driver, a traffic stop also effectuates a seizure of the passenger); Delaware v. Prouse, 440 U.S. 648, 663 (1979) (stating that because a random stop of a 
to investigate a traffic offense, when their actual reason for the stop is not supported by probable cause? During the founding era of America, James Otis Jr. stirred revolutionary fervor when he rallied against the British's use of writs of assistance to search the homes and businesses of colonists living in Massachusetts. ${ }^{30}$ Otis told a British court that the writs afforded "a power that places the liberty of every man in the hands of every petty officer." 31 That's exactly what pretext stops allow. ${ }^{32}$ They allow officers to pick and choose who to stop and question.

Under normal circumstances, Montgomery police would not have arrested a white pastor for driving thirty miles an hour in a twenty-five mile-per-hour zone. Martin Luther King Jr., however, was arrested and jailed. Race mattered. Likewise, many of the pretext stops currently conducted on America's roads and highways would not occur but for the police's desire to discover illegal narcotics, guns, or other evidence of crime. "It is the fact of the departure from the accepted way of handling such cases that makes the officer's conduct arbitrary, and it is the arbitrariness that in this context constitutes the Fourth Amendment violation ....”33 Nor is the constitutional evil

motorist is a seizure under the Fourth Amendment, police must have probable cause or reasonable suspicion that the motorist committed a traffic offense or other crime).

30. See 2 John AdAms, Legal PAPers of John AdAms 139-42 (L. Kinvin Wroth \& Hiller B. Zobel eds., 1965).

31. Id. at 141-42.

32. Cf. Citron, supra note 28, at 1108 ("The principal problem with the Whren [v. United States, 517 U.S. 806 (1996) (ruling that pretext stops do not violate the Fourth Amendment)] rule is that it transmogrifies the traffic law into the twenty-first century equivalent of the general warrant-police can stop whomever they want on the road, and for whatever reason, as long as they can claim probable cause to suspect some minor, technical violation of the traffic laws.”); see also Barbara C. Salken, The General Warrant of the Twentieth Century? A Fourth Amendment Solution to Unchecked Discretion to Arrest for Traffic Offenses, 62 TEMP. L. REV. 221, 224 (1989) ("[T]he authority to arrest for a traffic offense creates power to search tantamount to the unlimited and arbitrary authority that led to the adoption of the [F]ourth [A]mendment.”).

33. 1 LAFAVE, supra note $17, \S 1.4(\mathrm{e})$, at 170 ; [JH: this can be short cite according to BB 4.2] Anthony G. Amsterdam, Perspectives on the Fourth Amendment, 58 MinN. L. REV. 349, 366 (1974) (citation omitted) (ascribing to the Framers of the Fourth Amendment "not merely an appreciation but a concern that one evil of the existence of arbitrary power is the inevitability of its discriminatory exercise.”). 
eliminated by the requirement that police have probable cause of a traffic offense before they are permitted to stop a vehicle: "[G]iven the pervasiveness of such minor offenses and the ease with which law enforcement agents may uncover them in the conduct of virtually everyone, that difference hardly matters . . ..”34

Finally, in the rare case where probable cause or other objective evidence of a traffic violation is lacking, an officer can always "fabricate" probable cause. ${ }^{35}$ In modern times, this practice is known as "testilying." ${ }^{36}$ These practices seem to contradict the Supreme Court's

34. 1 LAFAVE, supra note 17, § 1.4(e), at 173; see also Bowers, supra note 15, at 155 ("In petty public-order cases, probable cause merely translates to a troubling form of 'constitutional carte blanche'-a plenary authority to harass and humiliate, to constrain and coerce, to behave in a manner antithetical to the purpose of the legality principle 'as an important prophylaxis against the arbitrary and abusive exercise of discretion in the enforcement of the penal law."”) (citations omitted).

35. The classic description of this phenomenon was provided by Jerome Skolnick:

[T] he policeman perceives his job not simply as requiring that he arrest where he finds probable cause. In addition, he sees the need to be able to reconstruct a set of complex happenings in such a way that, subsequent to the arrest, probable cause can be found according to appellate court standards. In this way, as one district attorney expressed it, "the policeman fabricates probable cause." By saying this, he did not mean to assert that the policeman is a liar, but rather that he finds it necessary to construct an ex post facto description of the proceeding events so that [they can] conform to legal arrest requirements, whether in fact the events actually did so or not at the time of the arrest. Thus, the policeman respects the necessity for “complying” with the arrest laws. His “compliance,” however, may take the form of post hoc manipulation of the facts rather than before-the-fact behavior. Again, this generalization does not apply in all cases. ... . But when he sees the case law as a hindrance to his primary task of apprehending criminals, he usually attempts to construct the appearance of compliance, rather than allow the offender to escape apprehension.

JEROME H. SKOLNICK, JUSTICE WiTHOUT TRIAL: LAW ENFORCEMENT IN DEMOCRATIC SOCIETY 214-15 (2d ed. 1975).

36. See Christopher Slobogin, Testilying: Police Perjury and What to Do About It, 67 U. ColO. L. REV. 1037 (1996); Joseph Goldstein, Police 'Testilying' Remains a Problem. Here Is How the Criminal Justice System Could Reduce It, N.Y. TIMES (Mar. 22, 2018), www.nytimes.com/2018/03/22/nyregion/police-lying-new- 
frequent pronouncements that "the 'core,' 'basic purpose' and 'central concern' of the Fourth Amendment have to do with protecting liberty and privacy against arbitrary governmental interference.” ${ }^{37}$ Put another way, precedent tells us that pretext traffic stops should be forbidden under the Fourth Amendment.

Sadly, but not surprisingly, the Supreme Court of the United States came to the opposite conclusion. In a unanimous opinion, Whren $v$. United States held that whenever police have probable cause to believe that a motorist has violated a traffic law, a stop is constitutionally reasonable under the Fourth Amendment. ${ }^{38}$ The subjective intent or motivation of the police, including police motives based on racial stereotypes or bias, are constitutionally irrelevant. ${ }^{39}$ The only thing that mattered to the Court was the existence of probable cause that a traffic violation occurred. Speaking for the Justices, Justice Scalia explained: "For the run-of-the-mine case, which this surely is, we think there is no realistic alternative to the traditional common-law rule that probable cause justifies a search and seizure."40

\section{THE IMPACT OF WHREN V. UNITED STATES}

The facts of Whren occurred on June 10, 1993, when two plainclothes vice-squad officers, Ephraim Soto Jr. and Homer Littlejohn, were patrolling a "high drug area" of Washington, D.C. ${ }^{41}$ The officers observed two young black men, Michael Whren and James Brown, riding in a Nissan Pathfinder with temporary tags. ${ }^{42}$ The officers were suspicious of the Pathfinder because it waited at a stop sign for over

york.html; Joseph Goldstein, Promotions, Not Punishments, for Officers Accused of Lying, N.Y. TIMES (Mar. 19, 2018), www.nytimes.com/2018/03/19/nyregion/newyork-police-perjury-promotions.html; Joseph Goldstein, 'Testilying' by Police: A Stubborn Problem, N.Y. TIMES (Mar. 18, 2018), www.nytimes.com/2018/03/18/nyregion/testilying-police-perjury-new-york.html.

37. 1 LAFAVE, supra note $17, \S 1.4(\mathrm{f})$, at 186 (citations omitted).

38. Whren v. United States, 517 U.S. 806 (1996).

39. Id. at 813 (stating that prior precedents "foreclose any argument that the constitutional reasonableness of traffic stops depends on the actual motivations of the individual officers involved”).

40. Id. at 819 .

41. Id. at 808 .

42. Id. 
twenty seconds, which they deemed too long. ${ }^{43}$ They also claimed to have observed Brown, the driver, look into Whren's lap. ${ }^{44}$ The officers initiated the traffic stop because the pause at the stop sign violated a D.C. traffic regulation that requires drivers to pay "full time and attention" to their vehicle while driving. ${ }^{45}$ The officers made a U-turn to stop the car, at which point Brown allegedly turned right without signaling and sped off. ${ }^{46}$

Even though a D.C. police department regulation prohibited plainclothes vice officers-like Soto and Littlejohn-from making routine traffic stops unless they observed a violation "so grave as to pose an immediate threat to the safety of others," 47 they nonetheless stopped the Pathfinder. ${ }^{48}$ "The reason for the stop was obviously pretext." 49 As soon as Soto approached the driver's side of the car, he observed what appeared to be two plastic bags of crack cocaine. ${ }^{50}$ Brown and Whren were arrested and the vehicle was searched, recovering more narcotics. ${ }^{51}$

Brown and Whren were indicted on federal drug offenses. ${ }^{52}$ During pre-trial motions, they argued that the legality of a traffic stop should not turn on whether a reasonable officer could conduct a stop, but whether a reasonable officer would conduct a stop. ${ }^{53}$ And no reasonable plainclothes vice officer would have made this stop because it was barred by departmental regulations. ${ }^{54}$ But the lower courts rejected the defendants' Fourth Amendment challenge that the stop was

43. Id.

44. Id.

45. Id. at 810 .

46. Id. at 808 .

47. Id. at 815 .

48. Id. at 808,815 .

49. Bowers, supra note 15 , at 156.

50. Whren, 517 U.S. at 808-09.

51. Id. at 809 .

52. Id.

53. Id. at 809-10.

54. It comes as no surprise that the officers were apparently not disciplined for violating departmental rules. See Kevin R. Johnson, The Song Remains the Same: The Story of Whren v. United States, in RACE LAW STORIES 419, 439 (Rachel F. Moran \& Devon W. Carbado eds., 2008) ("Nothing appears to have come of the fact that 
unconstitutional, stating that the officers acted in accordance with a normal traffic stop, even though department regulation prohibited such stops. $^{55}$

In the Supreme Court, racial profiling was a central plank of the defendants' constitutional claim. Emphasizing the lack of objective evidence that Brown and Whren were involved in narcotics activities, the defendants argued that they were stopped because of their race. ${ }^{56}$ They told the Court that racially-biased traffic enforcement was widespread throughout the country. ${ }^{57}$ Indeed, the year the Court decided Whren, court cases and other reports indicated that black motorists were targeted for pretextual traffic stops in various jurisdictions. For example, a New Jersey trial court found that New Jersey State Troopers had a de facto police practice of targeting black motorists for investigations and arrests on the southern portion of the New Jersey Turnpike. $^{58}$ In North Carolina, an analysis of the 1995 patrol records of the Special Emphasis Team of the North Carolina Highway Patrol, whose goal was to interdict narcotics through traffic stops on Interstates 85 and 95, found that officers on the Special Emphasis Team "charged black male drivers [with traffic offenses] at nearly twice the rate of other troopers working the same roads." 59 The study found that black male drivers received almost $45 \%$ of the traffic citations issued by the Team, while black male drivers received only $24.2 \%$ of the traffic citations issued by other North Carolina troopers patrolling the same highways. ${ }^{60}$ Moreover, the study explained that an independent statistical expert believed that it was "wildly improbable" that two groups of troopers patrolling the same roads would produce such disparate results by chance. ${ }^{61}$ In their argument to the Court, the defend-

[the officers] . . . violat[ed] departmental regulations. Both officers continued serving on the vice squad for many years.”).

55. Whren, 517 U.S. at 809.

56. Id. at 810 .

57. Id.

58. State v. Soto, 734 A.2d 350, 360 (N.J. Super. Ct. Law Div. 1996).

59. Joseph Neff \& Pat Stith, Highway Drug Unit Focuses on Blacks, News \& OBSERVER (Raleigh, N.C.), July 28, 1996, at A1.

60. Id.

61. Joseph Neff \& Pat Stith, Could It Happen by Chance?, NEws \& OBSERVER (Raleigh, N.C.), July 28, 1996, at A17. 
ants in Whren insisted that if a traffic violation always justifies stopping a motorist, police will abuse their power and use traffic offenses to evade otherwise applicable Fourth Amendment safeguards that prevent stopping and questioning motorists unless police have probable cause or reasonable suspicion that the motorist is engaged in criminal conduct. ${ }^{62}$

As mentioned above, none of this evidence or legal argument persuaded the Justices to declare pretext stops unreasonable under the Fourth Amendment. In fact, the Court was quite dismissive of the defendants' constitutional arguments. After Whren, a vehicle stop is legal provided an officer can identify any traffic offense or minor violation of the law-no matter the officer's real reason for the stop. The result and message in Whren were not lost on law enforcement officials. Writing in Police Chief Magazine, which describes itself as the professional voice of law enforcement, Roy Caldwell Kime recognized the importance of the case and the fact that pretext stops are a staple of law enforcement procedure. ${ }^{63}$ Kime noted that had Whren been decided differently, "a major shift in the way crimes are investigated and prosecuted in the United States would have occurred." 64 Instead, according to Kime, the result in Whren "preserve[d]" the way police "use traffic stops to uncover other criminal activities." 65 The message to police was clear. As one instructor for the California Highway Patrol told another author: “After Whren ... the game was over. We won.”66

On the other hand, Professor Wayne R. LaFave, the nation's foremost scholar on the Fourth Amendment, noted that the Whren Court's analysis of its own precedents was, "to put it mildly, quite disappointing." 67 According to LaFave, Whren "managed to trivialize

62. Whren, 517 U.S. at 816-18.

63. Roy Caldwell Kime, U.S. Supreme Court Rules on Asset Forfeiture and Traffic Stop Evidence, POLICE CHIEF, Aug. 1996, at 10.

64. Id.

65. Id. The Police Chief article made no mention of the racial disparities generated by pretext stops.

66. Webb, supra note 17, at 127; cf. EPP ET AL., supra note 14, at 159 (commenting that the "technical requirement to have a lawful justification for a stop offers no meaningful limitation on officers' authority to make stops”).[JH: should be the same citation sentence BB 1.2 and 1.3]

67. 1 LAFAVE, supra note 17, § 1.4(f), at 193. 
what in fact is an exceedingly important issue regarding a pervasive law enforcement practice." ${ }^{8}$ When this assessment is combined with the fact that the upshot of Whren means that police are conferred with "virtual carte blanche to stop people because of the color of their skin or for any other arbitrary reason," 69 Whren ranks as one of the Court's worst opinions in the last thirty years and is deserving of the vast criticism it has received.

Over twenty years ago, one of us criticized the result in Whren. ${ }^{70}$ Indeed, condemnation of Whren's holding and reasoning has been widespread and continues unabated. ${ }^{71}$ While there are no signs that the current Court sees any reason to question, let alone reconsider, its holding in Whren, the ramifications of Whren are significant. ${ }^{72}$ "More than 20 million Americans are stopped each year for traffic vi-

68. Id.

69. Id. $\S 1.4(\mathrm{e})$, at 171 (citation omitted).

70. Tracey Maclin, Race and the Fourth Amendment, 51 VAND. L. REV. 333 (1998); see also Tracey Maclin, United States v. Whren: The Fourth Amendment Problem with Pretextual Traffic Stops, in We Dissent: TAlking BaCK to THE REHNQUIST COURT 90-101 (Michael Avery ed., 2009).

71. See 1 LAFAVE, supra note 17, § 1.4(f), at 176 n.86 (citing articles criticizing Whren); see id. at $187 \mathrm{n} .126$ (citing cases and articles discussing the use of race by police in drug courier profiles and in the enforcement of traffic laws).

72. Recently, Justice Ginsburg, who joined the Whren opinion without qualification, acknowledged the criticism Whren has generated. See District of Columbia v. Wesby, 138 S. Ct. 577, 593-94 (2018) (Ginsburg, J., concurring). She also stated that, "I would leave open, for reexamination in a future case, whether a police officer's reason for acting, in at least some circumstances, should factor into the Fourth Amendment inquiry.” Id. (emphasis added). While Justice Ginsburg's statement indicates that some members of the Court are aware of the criticism heaped on Whren, her statement does not repudiate, let alone call for a reconsideration, of Whren. A case filed in the 2017-2018 Term would have given the Court an opportunity to do so. See United States v. Johnson, 874 F.3d 571 (7th Cir. 2017) (en banc), cert. denied, No. 17-1349, 2018 WL 1470947 (Oct. 1, 2018) (asking the Court to decide whether the Fourth Amendment forbids a pretextual seizure of a motorist based solely on probable cause to suspect a civil parking infraction). 
olations, making this one of the most common ways in which the public interacts with the police." ${ }^{73}$ All motorists violate traffic codes frequently and with regularity. ${ }^{74}$ When this fact is combined with the knowledge that numerous studies demonstrate that racial minorities are stopped at higher rates than white motorists, ${ }^{75}$ the consequence is that "[l]aw enforcement becomes a matter of 'picking the man and then searching the law books ... to pin some offense on him.",76

Further, there is another, deadly, aspect of pretextual traffic stops that we have not previously highlighted and has been ignored by the Court but is no less deserving of the nation's attention. Pretext stops cause "problems for real people with real names," are "hardly

73. EMMA PIERSON ET AL., A LARGE-SCALE ANALYSIS OF RACIAL DisPARITIES IN Police Stops Across the United States 1 (June 18, 2017), https://5harad.com/papers/traffic-stops.pdf.

74. HARRIS, supra note 17, at 31 (stating that the consequence of the nation's many traffic laws means that "no driver can go for even a short drive without violating some aspect of the traffic code. And since there are no perfect drivers, everyone's a violator."); Bowers, supra note 15, at 151 ("Indeed, the overwhelming majority of motorists break vehicle and traffic laws on an almost daily basis.”).

75. EPP ET AL., supra note 14, at 26 ("Police stop and search racial minorities at disproportionately high rates, and these disparities have grown wider in recent years.”); HARRIS, supra note 17, at 72 (“The data on stops are incontrovertible. The information comes from many cities and involves many different police departments and law enforcement contexts. ... [A]ll of the data point in the same direction: minorities are stopped, questioned, and searched in numbers far out of proportion to their presence in the driving population.”).

76. Bowers, supra note 15, at 156; see also PAUl Butler, CHOKEHOLD: POLICING BLACK MEN 59-60 (2017):

A cop friend of mine invented a game that tells you everything you need to know about the extraordinary consequences of Whren. The cop takes my law students on ride-alongs in his squad car so they can see what it's like to be a police officer. The game is called Pick a Car. My friend tells the students to pick any car they see on the street and he will legally stop it. He says that he can follow any driver and within a few blocks he or she will commit some traffic infraction. Then he turns on his siren and flashing lights. He can order the driver and passenger to exit their vehicle. He can pat them down if he feels like his safety is threatened. This gives him an enormous amount of power. As a practical matter, if you are driving a car, he can stop you at will. 
trivial and anything but hypothetical," 77 and sometimes fatal. This lethal phenomenon is evident when we recall recent events and the names of black motorists stopped for trivial traffic violations and then killed by police: Philando Castile was pulled over for a cracked tail light. Sandra Bland was pulled over for failing to use a turn signal when changing lanes. Walter Scott was pulled over for a broken brake light. Castile, Bland, and Scott would not live to challenge the police decision to stop them.

Philado Castile was a black thirty-two-year-old school cafeteria worker when he was pulled over by police officer Jeronimo Yanez in Falcon Heights, Minnesota, on July 6, 2016, allegedly for a cracked tail light. ${ }^{78}$ This wasn't Philando's first traffic stop. “In a 13-year span, Philando Castile was pulled over by police in the MinneapolisSt. Paul region at least 49 times, an average of about once every three months, often for minor infractions." 79 Philando’s girlfriend, Diamond Reynolds, who was in the passenger seat, says that when Officer Yanez approached the vehicle, Philando tried to tell him that he was carrying a gun with a legal permit. ${ }^{80}$ Philando was reaching for his identification when Officer Yanez shot him several times, killing him while Diamond and Philando's four-year-old daughter watched. ${ }^{81}$ A video posted by Diamond of the incident went viral on a number of social media platforms. ${ }^{82}$

Walter Scott was fifty-years-old when North Charleston police officer Michael Slager stopped him. After telling Scott that he was stopped because his brake light was out, Slager returned to his cruiser

77. Bowers, supra note 15, at 140.

78. Sharon LaFraniere \& Mitch Smith, Philando Castile Was Pulled Over 49 Times in 13 Years, Often for Minor Infractions, N.Y. TIMES (July 16, 2016), https://www.nytimes.com/2016/07/17/us/before-philando-castiles-fatal-encounter-acostly-trail-of-minor-traffic-stops.html.

79. Id.

80. Id.

81. Id.

82. See Mark Berman, What the Police Officer Who Shot Philando Castile Said About the Shooting, WASH. PosT (June 21, 2017), https://www.washingtonpost.com/news/post-nation/wp/2017/06/21/what-the-police-officer-who-shotphilando-castile-said-about-the-shooting/?utm_term=.aab9778a62d3. 
to check Scott's identification. ${ }^{83}$ A few minutes later, Scott exited his vehicle and began to run away from the scene. ${ }^{84}$ Cell phone footage taken from a bystander shows Slager shooting Scott five times in the back, just "for running away, simply for having a broken taillight.",85 In December 2017, Slager was sentenced to twenty years for murdering Walter Scott. ${ }^{86}$

And then there is the tragic and mysterious death of Sandra Bland in July 2015. The day after an interview with Prairie View A\&M University in Texas, Bland was stopped by Texas State Trooper Brian Encinia. ${ }^{87}$ Encinia claims he stopped Bland for changing lanes without using a turn signal. ${ }^{88}$ Dash camera footage of the incident reveals that a back-and-forth ensued between Bland and Encinia after Encinia asked her to put out her cigarette, which she refused. ${ }^{89}$ Bland was eventually ordered from the vehicle, slammed to the pavement, handcuffed, and arrested. ${ }^{90}$ "One might respond that there was . . . no need for Bland to lash out - that she mocked him, just as he mocked her. But only one of them was a professional. More to the point, only one of them had the law at his back."91 Encinia arrested Bland, who was later charged with assaulting a public servant. ${ }^{92}$ Three days later,

83. See Meridith Edwards \& Dakin Andone, Ex-South Carolina Cop Michael Slager Gets 20 Years for Walter Scott Killing, CNN (Dec. 7, 2017) http://www.cnn.com/2017/12/07/us/michael-slager-sentencing/index.html.

84. Id.

85. Id.

86. Id.

87. See Bowers, supra note 15 , at 179.

88. See id.

89. See id. at 180-81 for a revealing transcript of the exchange between Bland and Encinia.

90. Id. at 181-82.

91. Id. at 182.

92. Id. 
Bland was found dead in her jail cell; the cause of death was determined suicide by asphyxiation. ${ }^{93}$ In September 2016, Bland's family settled for close to $\$ 2$ million in a wrongful death suit. ${ }^{94}$

While some readers may strongly disagree with this assessment, we believe Whren's holding contributed to the deaths of Castile, Scott, and Bland. Perhaps Whren does not encourage police to target blacks for traffic enforcement, but it certainly erects no constitutional obstacles to arbitrary and biased policing. ${ }^{95}$ Recall the reaction to Whren from the instructor for the California Highway Patrol: "After Whren ... the game was over.[JH: ellipses shouldn't end the line] We won." 96 This instructor meant that Whren blessed pretext stops, notwithstanding the arbitrary and discriminatory impact caused by such stops. Nationwide, police have grasped the authority given by Whren and used it as a tool to perform arbitrary seizures to troll for evidence of criminality despite lacking objective evidence for their investiga-

93. Id.; see also Debbie Nathan, What Happened to Sandra Bland?, THE NATION (Apr. 21, 2016), https://www.thenation.com/article/what-happened-to-sandra-bland/.

94. Mark Berman, Sandra Bland's Family Says They Reached a \$1.9 Million Settlement in Wrongful Death Lawsuit, WASH. Post (Sept. 15, 2016), https://www.washingtonpost.com/news/post-nation/wp/2016/09/15/sandra-blandsfamily-reportedly-reaches-settlement-in-wrongful-death-lawsuit/?utm_term=.8bf1fe1b99b4.

95. Devon W. Carbado, From Stopping Black People to Killing Black People: The Fourth Amendment Pathways to Police Violence, 105 CALIF. L. REV. 125, 129 (2017) ("The claim that the Court enables and sometimes expressly authorizes racial profiling might sound like hyperbole, but it is not.”). Concededly, Whren agreed with the defendants' claim that selectively targeting blacks for traffic enforcement was unconstitutional and suggested a constitutional claim against race-based enforcement of traffic laws would be available under the Equal Protection Clause of the Fourteenth Amendment. See Whren v. United States, 517 U.S. 806, 813 (1996). For too many reasons to list here, this suggestion should not be taken seriously. See, e.g., 1 LAFAVE, supra note 17, § 1.4(f), at 189-92; Maclin, Race and the Fourth Amendment, supra note 70, at 337 n.22; David Sklansky, Traffic Stops, Minority Motorists, and the Future of the Fourth Amendment, 1997 SuP. CT. REV. 271, 326.

96. Webb, supra note 17 , at 127. 
tions and intrusions. When seen from this angle, the Court's interpretation of the Constitution becomes a sword for the police rather than a shield for the individual. ${ }^{97}$

Ultimately, the authority given by Whren facilitates part of the bias contaminating America's criminal justice system. ${ }^{98}$ It promotes arbitrary and racist policing. Although he was not focusing solely on the problem of pretextual traffic stops, what Paul Butler said about how America's law enforcement officers enforce the nation's criminal codes captures the essence of our attack on Whren:

The problem is the criminal process itself. Cops routinely hurt and humiliate black people because that is what they are paid to do. Virtually every objective investigation of a U.S. law enforcement agency finds that the police, as policy, treat African Americans with contempt. In New York, Baltimore, Ferguson, Chicago, Los Angeles, Cleveland, San Francisco, and many other cities, the U.S. Justice Department and federal courts have stated that the official practices of police departments include violating the rights of African Americans. The police kill, wound, pepper spray, beat up, detain, frisk, handcuff, and use dogs against blacks in circumstances in which they do not do the same to white people. ${ }^{99}$

Even the most privileged (and innocent) black Americans cannot escape the humiliation of being stopped, told to exit their vehicle,

97. Cf. DAvid K. Shipler, The Rights of the People: How Our SeARCH FOR SAFETY INVADES OUR LIBERTIES 41 (2011) (describing reliance on the reasonable suspicion standard rather than the probable cause standard contained in a memo for a special unit of the Washington, D.C., police department that uses traffic stops to look for guns: "For too long police officers have been trained to view the Constitution of the United States and its judicial interpretations as placing rigid restrictions on what law enforcement personnel can do on the street while shielding criminals from detection. .. . The members of the ... Gun Recovery Unit have viewed the Constitution and its associated case law as a law enforcement sword rather than a shield.”).

98. See JAMES FORMAN, JR., LOCKING UP OUR OWN: CRIME AND PUNISHMENT IN BLACK AMERICA 197-215 (2017) (describing how pretext stops contribute to racial disparities in America's criminal justice system).

99. BUTLER, supra note 76, at 2-3 (citations omitted). 
and placed in handcuffs, or of having their hands put on the hood of a vehicle and being frisked for weapons. ${ }^{100}$ No person of color is immune. ${ }^{101}$ This reality teaches us that "there is plenty of fear to go around.”102 Police fear black men because they associate blacks with violence and criminality. ${ }^{103}$ At the same time, black men do not trust the police. "Even black men who share no other problem with the black underclass share this one. The most successful, respectable

100. See Bryan Stevenson, Just Mercy: A Story of Justice And REDEMPTION 38-44 (2014) (detailing the author's account of an evening sitting in his car listening to music outside of his midtown Atlanta apartment when two officers approached his vehicle. Stevenson got out of his car to enter his apartment when officers drew their weapons and yelled “[m]ove and I'll blow your head off," worried Stevenson may be a suspected burglar in the area); see also Devon W. Carbado, (E)Racing the Fourth Amendment, 100 MiCH. L. REV. 946, 953-64 (2002) (providing examples where Carbado recounts a number of his first interactions with police after moving to the United States from the United Kingdom). For poor blacks living in urban areas, the experience is worse and routine. See SHIPLER, supra note 97, at 5563, 65-71, 83-84 (describing police encounters while riding with a Gun Unit of the D.C. police department):

Most citizens who are searched without giving voluntary consent don't go to court for the simple reason that they are entirely innocent. ... [T]heir experiences add up to an invisible record across the United States of countless unconstitutional searches. Each night, the [Gun Unit] leaves dozens of such victims in its wake. Rushing through blocks and courtyards, the officers consider the entire shift a success if a single gun is found, even when numerous innocents are stopped and frisked, their cars searched, their dignity assaulted, their zones of privacy invaded for naught. . . . But the officers don't keep track of the fruitless searches, and neither does anyone else.

Id. at 66.

101. Henry Louis Gates, Jr., Thirteen Ways of Looking at a Black Man, NEW YORKER, Oct. 23, 1995, at 56, 58-59, https://www.newyorker.com/magazine/1995/10/23/thirteen-ways-of-looking-at-a-black-man ("There's a moving violation that many African-Americans know as D.W.B.: Driving While Black.”).

102. Bowers, supra note 15 , at 172.

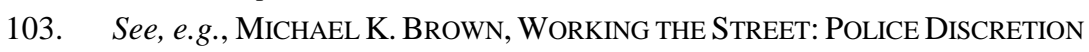
AND THE DILEMMAS OF REFORM 170 (1988) (“[T]he patrolman said he investigated the car in the first place because there were blacks in it, and with blacks 'there is always a greater chance of something wrong.'”); EPP ET AL., supra note 14, at 42 (citation omitted) ("Of the various social pathologies attributed to blacks, one directly implicates the police: the enduring stereotype that blacks are more likely to be violent, aggressive, and engage in crime.”); 
black man can find himself in a one-sided confrontation with a cop who thinks his first name is 'Nigger' and his last name is 'Boy.'”104 This distrust is manifested in African Americans' attitudes toward police pretext stops. "[B]lacks believe that the police are constantly watching them and treat them as if they don't belong; blacks fear that every small offense will result in a stop and that every encounter with the police can escalate and turn ugly.”"105

The result of this mix of police attitude towards blacks and blacks' distrust of the police is predictable: While officers "anticipate the possibility of violence, however remote, during a police stop, black drivers fear that any encounter with the police can, based [on] an inadvertent action or remark or misunderstanding, escalate into a humiliating and threatening experience." ${ }^{106}$ White Americans do not view police stops as ominous, or as a statement about their status as a citizen, or, most importantly, as life threatening. "[F]or whites[,] a stop is just a stop." 107 Not so for blacks. The only thing "normal” or routine about traffic stops "is the constant possibility of intrusive questions and searches, and the implication that the driver looks like a criminal.”108

There is another imbalance associated with police stops that is rarely publicly discussed. When police confrontations with black driv-

104. Don Wycliff, Blacks and Blue Power, N.Y. TIMES, Feb. 8, 1987, at E22, https://www.nytimes.com/1987/02/08/opinion/the-editorial-notebook-blacks-andblue-power.html.

105. EPP ET AL., supra note 14, at 47 (citation omitted).

106. Id.

107. Id. at 48; see also id. at 138:

Although white drivers do not like being stopped by the police, their dislike is fundamentally different than African Americans' fear of investigatory stops and searches, and it has different implications for whites' sense of their place in society. No white driver told us that he feared police stops. No white driver told us that she feared what might transpire during police stops — of searches, handcuffing, and arrest. No white driver told us that he tried to teach his children how to avoid trouble in police stops.

108. Id. at 118 . 
ers go bad or become deadly, "only the officer may rely upon his emotions and errors to claim an ex post excuse." 109 If a black driver or passenger makes an innocent mistake, for example, reaching for the glove compartment to retrieve proof of registration or an insurance card, or watching the officer too closely, ${ }^{110}$ or reaching for a cell phone, this action might be viewed by the officer as threatening, and the result might be the use of deadly force by the officer. ${ }^{111}$ This is another reason why blacks view police stops with anger and fear. Randall Kennedy accurately described the perspective shared by many African Americans regarding their encounters with the police:

If the police may properly view race as an indicia of suspicion, thereby making people of color more vulnerable to stops and questioning and all that stems from unwanted attention from the police, then it follows that people of color will have more reason than white persons to fear the police, regardless of their compliance with law. ${ }^{112}$

These feelings of fear and distrust of the police are not merely subjective or over-reactions to a few isolated encounters between black motorists and the police; numerous studies justify the views of many blacks.

\section{THe Numbers TODAY—“Driving WhILE BlacK” REMAINS A REALITY}

The past is the prologue. Evidence of arbitrary and discriminatory traffic enforcement is ever present. "Many studies find that the

109. Bowers, supra note 15, at 172 \& n.206 (quoting TA-NEHISI COATES, BETWEEN THE WORLD AND ME 71 (2015)) (“[T]he policeman who cracks you with a nightstick will quickly find his excuse in your furtive movements.”).

110. Cf. Bowers, supra note 15, at 185 (quoting video of a traffic stop where an officer told the driver that he stopped him "[b]ecause [the driver] made direct eye contact” with the officer).

111. See also id. at 188 (citation omitted) ("One false move (and a bit of bad luck) could describe the boundary between life and death-a killing that might be excused, after the fact, as an erroneous but understandable reaction to the officer's reasonable perceptions of danger.”).

112. RANDAll KenNeDy, RaCE, CRIME, AND THE LAW 153 (1997). 
police stop African Americans at higher rates than whites." ${ }^{113}$ A study published in 2014 found that blacks "are 270 percent more likely than whites to be subjected to an investigatory stop." 114 The same study found that the racial effects of who is stopped "is compounded in what happens during the investigatory stop." 115 Police conducting pretext stops "are five times more likely to search African Americans than whites, but they are much less likely to find a gun or contraband in searches of African Americans." "116 In 2018, we continue to see the consequences of Whren. Studies from the Department of Justice, Stanford University, and civil rights organizations indicate that racial disparities in traffic stops remain rampant.

\section{A. Stanford Open Policing Project}

Researchers at Stanford University set out to analyze racial disparities in police stops across the United States. ${ }^{117}$ Their study synthesized more than sixty million state patrol stops conducted in twenty states between 2011 and 2015. ${ }^{118}$ Some of the key findings include:

- Black drivers "[were] stopped more often than whites in over $80 \%$ of the locations" they considered. ${ }^{119}$

- "[B]lack drivers have 19\% higher odds of receiving a citation than white drivers," and that for "typical young male drivers" $72 \%$ of whites stopped for speeding receive a citation while $75 \%$ of black drivers stopped for speeding receive a citation. ${ }^{120}$

113. EPP ET AL., supra note 14, at 52 (citation omitted); id. at 72-73 (“African American drivers are more than two and a half times more likely than white drivers to be subjected to [pretext] stops. Gender compounds this disparity in pretext stops: African American men are almost four times more likely than white women to be subjected to these stops.”).

114. Id. at 155 .

115. Id.

116. Id. at 156.

117. See PIERSON, ET AL., supra note 73.

118. Id. at 1.

119. Id. at 4.

120. Id. at 6 . 
- Black drivers are searched in 3.5\% of stops, while white drivers are searched in only $2.0 \%$ of stops. ${ }^{121}$

- Black drivers are more likely than whites to undergo consent searches in the seven states where there is data available (Colorado, Florida, Massachusetts, Maryland, North Carolina, Texas, and Washington). More concretely, black drivers have 2.2 times the odds of white drivers, and Hispanic drivers have 1.9 times the odds of white drivers, of undergoing a consent search. ${ }^{122}$

- Examining arrests, they found that black drivers are arrested in $2.8 \%$ of stops, while white drivers are arrested in $1.7 \%$ of stops. ${ }^{123}$ Put another way, black drivers have 1.9 times the odds of being arrested compared to whites. ${ }^{124}$

- An "outcome test" revealed that black and white drivers who are stopped for traffic-related offenses and subsequently searched are both found to have contraband $28 \%$ of the time. In other words, black and white drivers have comparable "hit rates." ${ }^{125}$ However, a "threshold test" revealed that even though white and black drivers had comparable "hit rates," black drivers are "searched on the basis of less evidence, indicative of discrimination." 126 This test revealed that the bar for searching black drivers is less than white drivers. It found that the threshold for white drivers was $20 \%$ while the threshold for black drivers was $16 \% .^{127}$

\section{B. Department of Justice Special Reports}

During the years Barack Obama was president, the Department of Justice ("DOJ”) and its Bureau of Justice Statistics ("BJS”) authored

$\begin{array}{ll}\text { 121. } & \text { Id. } \\ \text { 122. } & \text { Id. } \\ \text { 123. } & \text { Id. at } 7 . \\ 124 . & \text { Id. } \\ \text { 125. } & \text { Id. at } 8-9 . \\ \text { 126. } & \text { Id. at } 9 . \\ 127 . & \text { Id. at } 11 .\end{array}$


a number of special reports that set out to discuss discrete issues in policing. Two such reports are relevant to the issue of pretext stops.

In Police Behavior During Traffic and Street Stops, the DOJ and BJS drew from data collected in the BJS 2011 Police-Public Contact Survey. ${ }^{128}$ The survey synthesized individuals' involuntary contact with police, namely during traffic stops and street stops. It also examined the individual's perception of police behavior during the stop, as well as the legitimacy of the stop. ${ }^{129}$ In relevant part, the study found that:

- Black drivers (14\%) were more likely than white drivers (9\%) to be told they were being stopped for a records check. ${ }^{130}$

- Black drivers (4.7\%) were nearly two times as likely as white drivers (2.6\%) to receive no justification for being stopped. ${ }^{131}$

- Black drivers (19\%) were more likely than white drivers (12.7\%) to be told they were being stopped because of a vehicle defect. ${ }^{132}$

- "White drivers pulled over by police (89\%) were more likely than black drivers (83\%) to think that the police behaved properly ...." "133

- "Regardless of the reason for the traffic stop, black (67\%) and Hispanic (74\%) drivers were less likely than white drivers (84\%) to believe the reason for the stop was legitimate.”134

128. Lynn Langton \& Matthew Durose, U.S. DeP'T of Justice, Police Behavior During TrafFic And Street StOPS, 2011 (Morgan Young ed., 2013), https://www.bjs.gov/content/pub/pdf/pbtss11.pdf.

129. Id. at 1 .

130. Id. at 4. Police cannot stop a vehicle to perform a "records check." Police need probable cause or reasonable suspicion of a traffic offense or criminal conduct before stopping a vehicle. See Delaware v. Prouse, 440 U.S. 648, 661 (1979).

131. LANGTON \& DUROSE, supra note 128 , at 4.

132. Id.

133. Id. at 3.

134. Id. at 4 . 
- "[A] greater percentage of black (7\%) and Hispanic (6\%) drivers were ticketed than white drivers (5\%)."135

- Black (6.3\%) and Hispanic (6.6\%) drivers were more likely to be searched by police after being stopped than white drivers (2.3\%). ${ }^{136}$

In Police Use of Nonfatal Force, 2002-11, the DOJ and BJS revealed that " $\mathrm{t}$ ]raffic stops involving an officer and driver of different races were significantly more likely to involve the threat or use of force (2.0\%), compared to traffic stops involving an officer and driver of the same race (0.8\%)."137 It also found that of police contact made during a traffic stop that involved threat or use of force, when the citizen was white, threat or use of force was used $0.8 \%$ of the time. ${ }^{138}$ When the citizen was black, however, threat or use of force was used $2.5 \%$ of the time. ${ }^{139}$ This study also found that in contact involving nonfatal force that resulted in a personal search of the individual, "[b]lacks (9.4\%) were more likely to experience a personal search than whites (2.8\%)."140

\section{Department of Justice Investigation of the Ferguson, Missouri Police Department}

In addition to authoring special reports around discrete issues like use of non-lethal force and police behavior during traffic and street stops, the DOJ has also, at the request of President Barack Obama, initiated a number of investigations into the patterns and practices of large metropolitan police departments. ${ }^{141}$ These investigations often

135. Id. at 7 .

136. Id. at 9 .

137. Shelley Hyland, Lynn Langton, \& Elizabeth Davis, U.S. Dep'T of Justice, Police Use of Nonfatal Force, 2002-11, at 8 (Lynne McConnell \& Jill Thomas eds., 2015), https://www.bjs.gov/content/pub/pdf/punf0211.pdf.

138. Id. at 4, tbl.3.

139. Id.

140. Id. at 8.

141. According to an NBC News report, "[u]nder the Obama Administration, the [Department of Justice] opened 25 investigations into police departments and 
were prompted by highly-publicized police shootings and killings of people of color during the Obama Administration. ${ }^{142}$ The investigations were initiated to determine whether police departments were engaging in patterns or practices of unconstitutional conduct and if that conduct disproportionately affected communities of color. ${ }^{143}$

The most publicized of these investigations was that of Ferguson, Missouri: a city that became a hotbed of racial tension and the epicenter of the Black Lives Matter movement following the tragic death of eighteen-year-old Michael Brown at the hands of Ferguson police officer Darren Wilson. At its core, the Ferguson investigation revealed "discriminatory intent" as a contributing factor to racial disparities in Ferguson's criminal justice process. ${ }^{144}$

The report stated: "Ferguson police officers from all ranks told us that revenue generation is stressed heavily within the police department, and that the message comes from City leadership."145 The report also observed that "Ferguson's police and municipal court practices both reflect and exacerbate existing racial bias, including racial stereotypes. Ferguson's own data establish clear racial disparities that adversely impact African Americans." 146 As a consequence of these official priorities and practices, "many [Ferguson police] officers appear to see some residents, especially those who live in Ferguson's predominantly African-American neighborhoods, less as constituents to be protected than as potential offenders and sources of revenue." ${ }^{147}$ The Justice Department study made plain that Whren encouraged the police practices that afforded the Ferguson police unchecked discretion to

sheriff's offices and was enforcing 19 [consent] agreements at the end of 2016, resolving civil rights lawsuits filed against police departments in Ferguson, Missouri; Baltimore, New Orleans, Cleveland and 15 other cities.” Pete Williams, AG Sessions Says DOJ to "Pull Back" on Police Department Civil Right Suits, NBC NEws (Feb. 28, 2017, 12:47 PM), https://www.nbcnews.com/news/us-news/ag-sessions-saystrump-administration-pull-back-police-department-civil-n726826.

142. See id.

143. See id.

144. U.S. DeP'T OF Justice, InVestigation of the Ferguson Police DEPARTMENT 2 (2015), https:/www.justice.gov/sites/default/files/opa/press-releases/attachments/2015/03/04/ferguson_police_department_report.pdf.

145. Id.

146. Id.

147. Id. 
stop vehicles and to generate revenue through fines and other court costs.

Some of the key findings from the Ferguson investigation include:

- "Data collected by the Ferguson Police Department ["FPD”] from 2012 to 2014 shows that African Americans account for $85 \%$ of vehicle stops, $90 \%$ of citations, and $93 \%$ of arrests made by FPD officers, despite comprising only $67 \%$ of Ferguson's population." 148

- “African Americans are more than twice as likely as white drivers to be searched during vehicle stops even after controlling for non-race based variables such as the reason the vehicle stop was initiated, but are found in possession of contraband $26 \%$ less often than white drivers, suggesting officers are impermissibly considering race as a factor when determining whether to search." 149

- “African Americans are more likely to be cited and arrested following a stop regardless of why the stop was initiated and are more likely to receive multiple citations during a single incident. From 2012 to 2014, FPD issued four or more citations to African Americans on 73 occasions, but issued four or more citations to non-African Americans only twice."150

Investigators and attorneys with the DOJ also collected narratives from citizens. One narrative depicts how pretextual stops are used to harass blacks:

In October 2012, police officers pulled over an African-American man who had lived in Ferguson for 16 years, claiming that his passenger-side brake light was broken. The driver happened to have replaced the light

148. Id. at 4 .

149. Id.

150. Id. 
recently and knew it to be functioning properly. Nonetheless, according to the man's written complaint, one officer stated, "let's see how many tickets you're going to get," while a second officer tapped his Electronic Control Weapon ("ECW") on the roof of the man's car. The officers wrote the man a citation for "tail light/reflector/license plate light out." They refused to let the man show them that his car's equipment was in order, warning him, "don't you get out of that car until you get to your house." 151

Ultimately, the DOJ report on the Ferguson Police Department depicted an organization that employs discriminatory and arbitrary procedures and practices aimed at African Americans living and working in Ferguson. The report describes "a pattern of [police] stops without reasonable suspicion and arrests without probable cause in violation of the Fourth Amendment; infringement on free expression, as well as retaliation for protected expression, in violation of the First Amendment; and excessive force in violation of the Fourth Amendment."152

A year after the DOJ report was issued, the DOJ and the City of Ferguson entered into a consent decree regarding many of the findings listed in the DOJ report. ${ }^{153}$ The consent decree was "meant to ensure protection of the constitutional and other legal rights of all members of the community, improve Ferguson's ability to effectively prevent crime, enhance both officer and public safety, and increase public confidence in the Ferguson Police Department." ${ }^{154}$

Interestingly, to protect the "constitutional" rights of persons living and working in Ferguson, the consent decree bars Ferguson police officers from employing pretext stops. ${ }^{155}$ Think about this propo-

151. Id. at 17.

152. Id. at 2-3.

153. Consent Decree, United States v. City of Ferguson, No. 4:16-cv-000180CDP (E.D. Mo. Mar. 17, 2016).

154. Id. at 1.

155. Id. at 19 ("FPD officers will not initiate an encounter with any person or stop any person, or attempt to do so, for the purpose of checking for warrants even 
sition: to protect the Fourth Amendment rights of blacks living in Ferguson, the federal government required that Ferguson police officers refrain from exercising police authority — pretextual traffic stops - that a unanimous Supreme Court had ruled was constitutional. Put another way:

In order to try to prevent the Ferguson police from treating African American residents unfairly, the police department's constitutional powers have to be curtailed. Not only is the Constitution, as interpreted by the Supreme Court, insufficient to protect black people from police abuse, it actually aids and abets the police abusers. ${ }^{156}$

The aftermath of the DOJ report and the resulting consent decree unflinchingly demonstrates how Whren fosters arbitrary and discriminatory police law enforcement.

The above statistics and reports demonstrate the breadth of the problem associated with pretext stops. But these studies cannot expose the human judgments that are responsible for the consequences and racial disparities caused by pretext stops. First, it is important to note that pretext stops are not always initiated by racist law enforcement officials or even individual officers. James Forman Jr.'s insightful book, Locking Up Our Own, describes how Eric Holder, the nation's first African American Attorney General, helped initiate Operation Ceasefire when he served as the first black United States Attorney for the District of Columbia in the early 1990s. ${ }^{157}$

The point of Operation Ceasefire was basic: "Stop cars, search cars, seize guns." 158 Specially trained units of the District of Columbia police department would patrol high-crime areas of the city looking for

where there is an alternative pretext for the stop, unless the officer knows the person's identity and that the person has outstanding warrants for his/her arrest, prior to the encounter."); id. at 20 ("FPD officers will not conduct pretextual stops except where the actual reason for the stop is to investigate a felony.").

156. BUTLER, supra note 76, at 190.

157. FORMAN, supra note 98, at 194-211.

158. Id. at 197. 
suspicious vehicles with the goal of searching for guns inside the cars. ${ }^{159}$ Any traffic offense would justify a stop and the officers would take it from there. Holder conceded the impact on the black community: "I'm not going to be naïve about it .... The people who will be stopped will be young black males, overwhelmingly." 160 The costs were worth it, however, to protect blacks from gun violence. Holder was not alone in embracing pretext stops as a way of reducing crime in poor black neighborhoods. "Holder's approach was embraced by the black police chiefs who were running departments in several major cities by the late 1990s." 161

But Holder did not acknowledge "the immense volume of innocent people who would have to be stopped in order to obtain a sizeable number of guns." 162 Holder and others who supported pretext stops in the District of Columbia should have known that such stops would rarely disclose guns; Holder's proposal was based in part on similar programs in Kansas City, Missouri, and Indianapolis, Indiana. The "Kansas City and Indianapolis studies showed how seldom guns were actually found. In Kansas City, police in the target area seized guns in only 3.57 percent of traffic stops, while in Indianapolis they found guns in less than 1 percent of traffic stops.” ${ }^{163}$ Most importantly, when unveiling his proposal, Holder did not discuss the inevitable resentment felt by innocent persons who would become the eventual subjects of pretext stops.

It is also important to understand that a pretext stop "is an institutionalized practice.”164 Deploying pretext stops to search for guns, as was done in the District of Columbia under Eric Holder's watch, or to look for drugs, as the New Jersey State Police did in the mid-1990s, are well-considered policy choices. Moreover, as one study has shown, "[p]olicies favoring proactive investigatory stops, by directing

159. Nancy Lewis, Holder Says Gun Campaign Will Enlist 50 D.C. Officers; U.S. Attorney to be Host of Summit this Week, WASH. Post, Mar. 8, 1995, at D1.

160. FORMAN, supra note 98, at 203.

161. Id. at 204 (noting that Bernard Parks, the black police chief in Los Angeles, and Charles Ramsey, who became the police chief in the District of Columbia in 1998, shared Holder's view).

162. Id. at 200.

163. Id. at 201 (citation omitted).

164. EPP ET AL., supra note 14, at 25. 
officers to look not for violations of the law but suspicious individuals, activate departments' and officers' implicit stereotypes of which neighborhoods and which individuals are suspicious." 165 These policy choices have consequences, some of which are extremely harmful. ${ }^{166}$ To confiscate a single illegal weapon, dozens of innocent motorists must be stopped, questioned, and sometimes have their vehicles searched while they are left standing on the side of the road to watch police rifle through their possessions. In urban areas, the innocent persons most affected are black males, and they deeply resent the experience. $^{167}$

Finally, high-ranking police officials and prosecutors are misguided when they dismiss the resentment felt by innocent persons as "victimology." 168 In our racially polarized nation, the consequences of pretext stops are vital. "Police stops convey powerful messages about citizenship and equality. Across millions of stops, these experiences are translated into common stories about who is an equal member of a rule-governed society and who is subjected to arbitrary surveillance and inquiry."169 Law enforcement officials should heed the advice of James Forman Jr. who observes that "pretext stops are a direct, easily remedied source of racial disparities in the criminal justice system, and they are entirely within the power of law enforcement to correct." 170

165. Id. at 50.

166. See supra text accompanying notes 73-94.

167. EPP ET AL., supra note 14, at 1-3.

168. Jeffrey Goldberg, The Color of Suspicion, N.Y. TIMES (June 20, 1999), https://www.nytimes.com/1999/06/20/magazine/the-color-of-suspicion.html. (quoting D.C. Police Chief's reaction to claims of racial profiling by the police: “'Not to say that it doesn't happen, but it's clearly not as serious or widespread as the publicity suggests,' says Chief Charles Ramsey of Washington. 'I get so tired of hearing that "Driving While Black" stuff. It's just used to the point where it has no meaning. I drive while black-I'm black. I sleep while black too. It's victimology. Black people commit traffic violations. What are we supposed to say? People get a free pass because they're black?'”).[JH: since there are no pincites for newspapers, I do not think you need a cite and then an id to have the quote]

169. EPP ET AL., supra note 14, at 2; id. at 113 ("African Americans are subjected to deeper investigatory intrusions not because they are poorer, less educated, more disrespectful, or more distrustful of the police than whites. It is a racial disparity, pure and simple.”).

170. FORMAN, supra note 98, at 214 (citation omitted). 
20181105 Maclin Reconcile WLR Clean Copy (Do Not Delete) 1/17/2019 11:13

\section{CONCLUSION}

The authors in this symposium were asked to consider how far America has come in the fifty years after the tragic assassination of Martin Luther King Jr. Of course, America has made substantial progress on several fronts that would have pleased Dr. King had he lived to see them. Many aspects of our criminal justice system, however, would have deeply disappointed King. We are confident that the continued and widespread use of pretext stops and their attended consequences would have offended King. Looking forward, America can honor Dr. King by ending pretext stops. 